\title{
Ekspresi Kasih dalam Karya Tari Dadalar
}

\author{
Yezyuruni Forinti ${ }^{\mathrm{a}, 1,{ }^{*}, \text { Eko Supriyanto }}{ }^{\mathrm{b}, 2}$ \\ a Jurusan Tari Fakultas Seni Pertunjukan Institut Seni Indonesia Surakarta \\ ${ }^{b}$ PUI-PT Choreographic and Artistic Research, Institut Seni Indonesia Surakarta \\ ${ }^{1}$ zaruny07@gmail.com \\ * Corresponding Author
}

Received 5 September 2021; accepted 13 Oktober 2021; published 3 November 2021

\begin{abstract}
Dadalar dance is motivated by an interest in the application of love in social life between humans. Every human being has their way of giving and receiving love which ultimately shapes the character of the human being. Environmental factors, father, and the Bible are three factors that encourage the creator to create this work. But the main factor is the father figure, a person who teaches many things, especially the knowledge of God and love. Dadalar dance works using the Partnering method, where this work is presented in a duet with two dancers. There is cooperation between dancers, so a sense of mutual help, mutual trust, support, and balance is needed. This work is a development of the traditional dances of North Maluku, namely Sarah Dabi dabi and Legu salai. The creation process includes the preparation stage and the cultivation stage. The preparation stage consists of observation and determination of the material. The cultivation stage interprets the results of exploration, improvisation, imagination, and unification.

Dadalar is presented in a duet of three parts, interpreted in sense, atmosphere, space, and time. This presentation emphasizes the importance of intensity and gives the audience space and time to enjoy and sense what is presented.
\end{abstract}

\section{KEYWORDS}

\author{
Dadalar \\ love \\ partnering \\ sense
}

This is an open access article under the CC-BY-SA license

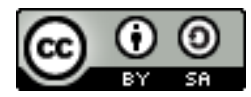

\section{Pendahuluan}

Dadalar diambil dari bahasa Sahu (merupakan nama suku asli yang mendiami Pulau Halmahera, dan kebanyakan bermukim di Kota Jailolo), yang memiliki arti "kasih sayang". Makna dari kasih sendiri adalah memberikan yang terbaik untuk orang lain, dan baik itu sangat membahagiakan, tidak merebut kebahagiaan orang lain dan membuka pintu hati untuk sebuah kasih. Menjadi orang yang peduli dan mengasihi orang lain terkadang memang sangatlah sulit karena disini kita harus mampu mengalahkan ego diri (Forinti 2021, 1). Berangkat dari pengalaman pengkarya tentang fenomena sosial di sekitar, bertemu dengan orang-orang yang mengalami kesepian emosional maupun sosial, mendorong pengkarya untuk menciptakan karya Dadalar yaitu tentang kasih sayang. Kasih sayang diartikan sebagai perasaan emosi yang lunak. Kasih sayang, perhatian, kepedulian, cinta, semuanya mampu dirasakan dari sosok yang memiliki kasih dalam dirinya.

Garapan karya tari ini akan disajikan dalam bentuk karya tari non-literer. Pengkarya akan mencoba menvisualisasikan ide garap mengenai spirit, suasana dan semangat yang muncul dari seorang demonstran, dalam sebuah jalinan koreografi yang meliputi ruang, gerak, waktu, tenaga, dan tema garap (Widyastutieningrum and Wahyudiarto 2014). Di samping itu, sebagai sebuah pertunjukan karya tari, tentunya memiliki konsep visual, serta komponen-komponen baik verbal maupun non verbal (Maryono 2015).

Karya tari Dadalar ditarikan dengan dua penari perempuan dan terdiri dari tiga bagian. Bagian pertama, ditarikan dengan satu penari yang menari dengan tempo irama pelan, penggambaran tentang manusia yang mencintai dan mengasihi dirinya sendiri. Bagian kedua, ditarikan dengan dua penari yang menggambarkan tentang manusia yang saling membutuhkan satu dengan yang lain, untuk itulah manusia perlu untuk saling mengasihi dan saling peduli satu dengan yang lain. Bagian ketiga, ditarikan dengan dua penari yang perlahan menemukan jati dirinya. Karya ini merujuk pada 
perspektif kasih dari personal pengkarya dengan sosok ayah. Dimana pengkarya menjadikan partner penari sebagai imajinasi untuk membuktikan bahwa kasih itu ada. Dimana partner sebagai bentuk support atau saling membantu satu dengan yang lain.

\section{Metode Penciptaan Karya Seni}

Penciptaan karya seni ini dilandasi dengan prinsip Re-Visiting (mengunjungi kembali situs-situs sejarah atau kebudayaan dengan melakukan sebuah rangkaian riset), Re-Questioning (mempertanyakan kembali asal muasal atau hakikat dengan memahami sejarah dan kebudayaan), dan Re-Interpreting (menerjemahkan kembali dengan elemen-elemen yang mengandung novelty dalam bentuk karya seni) (Supriyanto 2018, 222).

Proses penciptaan karya tari Dadalar melalui beberapa tahapan diantaranya tahap persiapan dan tahap penggarapan. Tahap persiapan dilakukan dengan cara observasi, untuk mengetahui dan memahami lebih dalam tentang kasih sayang yang terjadi. Observasi dilakukan dengan cara mengamati kehidupan orang-orang di sekitar yang bersinggungan dengan kasih sayang, seperti keluarga, teman, bahkan orang asing yang pengkarya temui, kemudian dilakukan penentuan materi untuk mencari dan menentukan materi untuk karya Dadalar. Materi yang menjadi dasar dari karya ini adalah tari tradisi yang berasal dari Maluku Utara yaitu Sarah dabi dabi dan Legu salai (Forinti 2021, 13-14).

Tahap penggarapan, pada tahap ini dilakukan proses eksplorasi yang bertujuan untuk mencari dan menemukan gerak yang dimunculkan dalam karya tari Dadalar. Eksplorasi dilakukan dengan dasar pengalaman empiris dan ketubuhan dalam mengembangkan tari tradisi Sarah Dabi-Dabi dan Legu Salai sebagai bahannya, serta digunakan teknik imajinasi untuk penciptaan rasa yang kuat dalam karya tari.

\section{Hasil dan Pembahasan}

\subsection{Deskripsi Karya Tari Dadalar}

Pada bagian ini akan dijelaskan mengenai karya tari Dadalar dilihat dari dimensi gerak, pola lantai, rias busana, musik, setting panggung dan tata cahaya.

\subsubsection{Gerak}

Karya ini terbagi dalam tiga bagian, bagian pertama menggambarkan tentang sisi dari manusia yang menikmati kesendirian, mencintai dan berusaha memahami diri sendiri. Pada bagian ini penari berjalan dengan tempo yang sangat pelan, berjalan mundur ke arah belakang, kemudian berjalan maju menuju sudut depan dan melakukan gerakan turun hingga jongkok membungkuk dan berdiri kembali dengan tempo yang pelan.

Bagian kedua menggambarkan tentang sisi dari manusia yang pada dasarnya saling membutuhkan dan bergantung satu dengan yang lain, manusia tidak dapat hidup sendiri tetapi membutuhkan manusia lain untuk menemukan jati diri. Bagian ini diawali dengan masuknya penari kedua ke area panggung dari sudut belakang, berjalan perlahan membentuk segitiga hingga bertemu penari pertama di titik kanan belakang. Selanjutnya komunikasi tubuh antar penari, saling bersentuhan punggung dengan punggung, mencoba menyampaikan rasa saling membutuhkan satu dengan yang lain.

Bagian ketiga menggambarkan penemuan jati diri, menemukan dan memahami diri sendiri. Bagian ini diawali dengan kedua penari berdiri di tengah panggung dengan posisi tidak sejajar, melakukan gerakan gelombang tubuh dengan teknik dorongan perut secara perlahan dengan motivasi berimajinasi melepaskan rasa yang mengganjal dari dalam diri. Gerakan ini dilakukan sambil menuju posisi masing-masing yaitu penari pertama ke tengah panggung dan penari kedua ke kiri panggung. Pada bagian terakhir ini menggambarkan akhir dari pencarian manusia akan jati dirinya.

\subsubsection{Pola Lantai}

Pola lantai bagian pertama, penari berada di sudut kiri depan kemudian berjalan mundur ke belakang membentuk garis diagonal dan kembali berjalan maju menuju sudut kiri depan panggung. 
Pola ini diperkuat juga dengan tata cahaya yang berbentuk seperti lorong memanjang di tengah kegelapan, memberi kesan tenang dengan suasana sepi.

Bagian kedua, penari berada di sudut kanan belakang panggung kemudian berjalan pelan menuju tengah panggung membentuk letter $\mathrm{L}$, kemudian kedua penari berpisah dan bergerak mengelilingi panggung membentuk kotak dan bertemu kembali di tengah panggung. Bagian ini menggambarkan tentang kepedulian akan satu dengan yang lain, dengan suasana yang tenang namun diperkuat dengan tata cahaya yang temaram sehingga memperkuat rasa khusyuk yang dihadirkan.

Bagian ketiga, penari berada di tengah panggung dengan posisi yang tidak sejajar. Penari pertama menuju ke tengah panggung dan penari kedua menuju ke kanan panggung membentuk sudut 45 derajat. Penari pertama perlahan berjalan mundur ke belakang panggung lalu belok ke kanan berjalan pelan keluar panggung dan menyisahkan penari kedua di kanan panggung. Bagian ini diperkuat dengan tata cahaya berwarna biru yang menggambarkan keteduhan dengan suasana yang tenang.

\subsubsection{Rias Busana}

Tata rias untuk penari, yang pertama wajah: wajah penari natura atau tanpa make up dengan tujuan untuk menampilkan wajah penari apa adanya. Sedangkan untuk busana, menggunakan dress berwarna merah maroon dengan lapisan belakang lebih panjang dari lapisan depan, dan bagian belakang terbuka sehingga menampakan punggung penari.
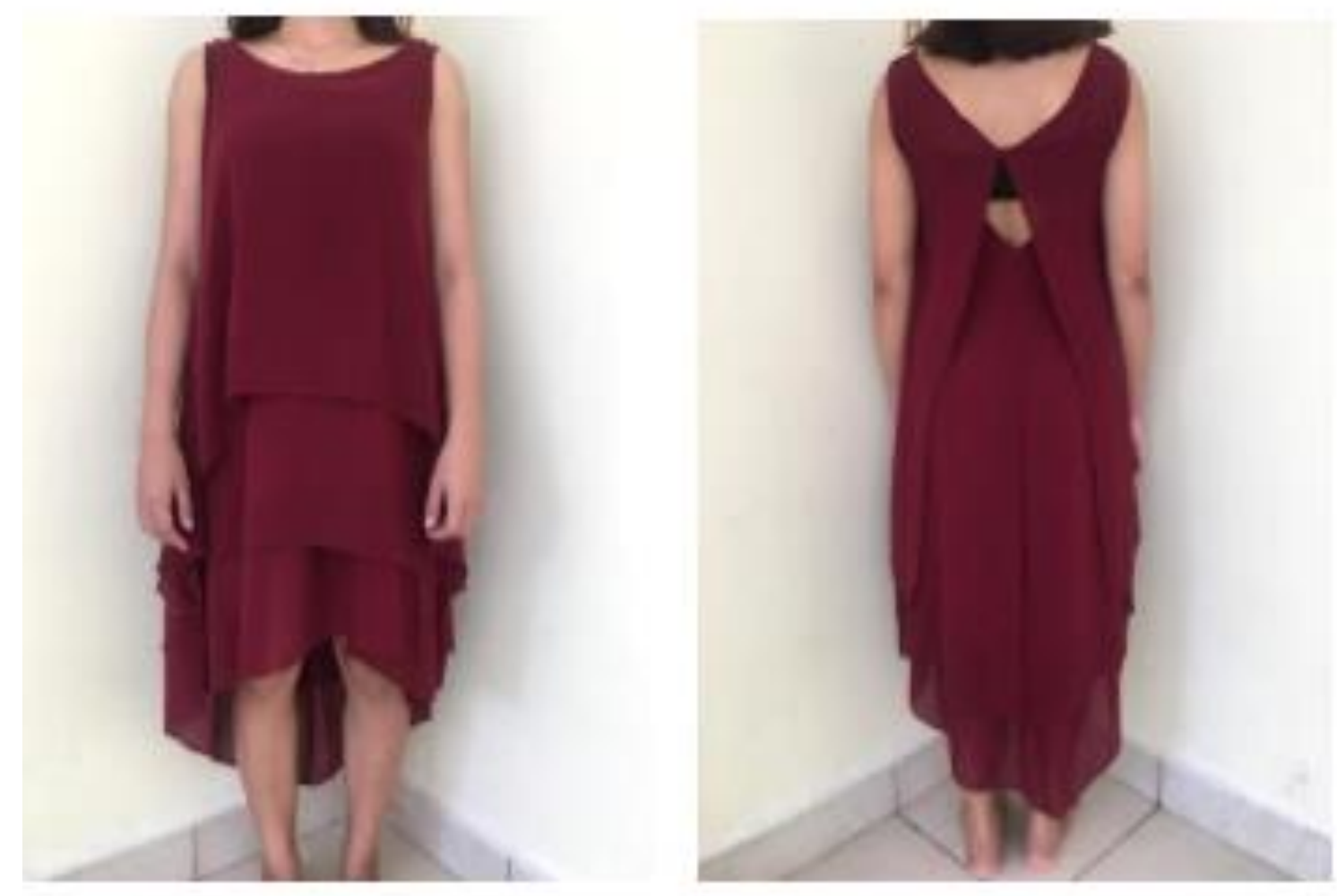

Gambar 1. Busana dalam karya tari Dadalar

\subsubsection{Musik}

Karya tari Dadalar menggunakan musik guna untuk membangun suasana sepi dan tenang yang menggambarkan kesendirian. Pada pertengahan bagian pertama, musik perlahan mulai masuk dan membangun suasana yang terasa semakin kuat.

Pada bagian kedua, menggunakan tambahan bunyi alat musik Cello dan Biola, yang mendukung suasana komunikasi tubuh antar kedua penari. Memberi penggambaran tentang sisi dari manusia yang pada dasarnya saling membutuhkan dan bergantung satu dengan yang lain, manusia tidak dapat 
hidup sendiri tetapi membutuhkan manusia lain untuk menemukan jati diri. Pada bagian ketiga, menggunakan vokal suara yang direkam dan menggunakan teknik membalik atau reverse. Vokal ini berisi ungkapan tentang kasih, bertujuan untuk membangun suasana dan rasa pada penari. Pada bagian ending, suara musik perlahan menghilang atau fade out.

\subsubsection{Setting Panggung dan Tata Cahaya}

Karya tari Dadalar dipentaskan menggunakan panggung dengan jenis panggung arena tertutup. Panggung arena adalah panggung yang penontonnya melingkar atau mengelilingi panggung. Pada bagian pertama, tata cahaya menggunakan lampu yang menyinari dari sudut kanan panggung membentuk garis diagonal dan terlihat seperti lorong yang memanjang kebelakang, kemudian bagian selanjutnya diterangi dengan cahaya lampu yang tidak terlalu terang untuk menciptakan suasana yang tenang sepi.

Pada bagian kedua, menggunakan lampu dengan cahaya intensitas tinggi dan arah pencahayaannya terpusat pada area tertentu dengan batasan yang jelas. Selanjutnya, menggunakan jenis lampu yang mampu menghasilkan warna terang atau warna netral di panggung. Pada bagian ketiga, menggunakan lampu dengan sentuhan warna biru namun redup untuk menciptakan suasana teduh dan tenang.

\subsection{Tinjauan Kritis Kekaryaan}

Selama proses penggarapan, pengkarya melakukan beberapa hal seperti latihan fisik, eksplorasi, dan juga improvisasi untuk menemukan materi baru. Dalam tahap ini, tentu ada beberapa hambatan yang dialami pengkarya, seperti kesulitan dalam menyampaikan dan merealisasikan ide yang ditemukan kepada penari, namun akhirnya hal ini bisa diatasi oleh pengkarya dengan menggunakan metode partnering dan imajinasi. Karya tari Dadalar merupakan karya yang diciptakan berdasarkan pengalaman empiris bagaimana mengenal kata kasih dan kaitannya dengan fenomena sosial yang melingkupinya. Setiap manusia memiliki cara sendiri untuk menerapkan kasih dalam kehidupannya. Demikianlah tinggal tiga hal ini, yaitu iman, pengharapan, dan kasih, dan yang paling besar diantaranya ialah kasih.

\section{Kesimpulan}

Karya Dadalar berangkat dari ketertarikan pengkarya terhadap penerapan kasih dalam kehidupan bersosial antar manusia. Setiap manusia memiliki cara sendiri untuk memberi maupun menerima kasih yang akhirnya menunjukan karakter dari manusia itu sendiri. Mengangkat fenomena sosial tentang kasih sayang yang terjadi dalam kehidupan bersosial, dimana setiap manusia selalu ingin dikasihi, diperhatikan, dan dipedulikan. Proses penciptaan karya tari Dadalar meliputi dua tahap yaitu tahap persiapan dan tahap penggarapan. Tahap persiapan terdiri dari observasi dan penentuan materi, sedangkan tahap penggarapan terdiri dari latihan fisik, eksplorasi, improvisasi, dan penyusunan atau penyatuan ide yang ditemukan. Karya ini berangkat dari dasar tari tradisi Maluku Utara, yaitu tari Legu salai dan Sarah dabi dabi. Selain terinspirasi dari pengenalan dan penerapan akan kasih, karya ini juga terinspirasi dari sosok ayah yang berperan penting. Dalam penerapan ide untuk karya ini, pengkarya lebih menegaskan pengolahan rasa pada setiap bagian dari koreografi karya Dadalar, karena kasih identic dengan rasa yang ada di dalam diri manusia. Selama proses penciptaan karya Dadalar, pengkarya mendapatkan banyak pengalaman dan pelajaran yang berharga, untuk itu besar harapan pengkarya untuk keberlanjutan karya Dadalar ke depannya. 


\section{Kepustakaan}

Forinti, Yezyurini. 2021. "Dadalar.” Institut Seni Indonesia Surakarta.

Maryono. 2015. Analisa Tari. Surakarta: ISI Press.

Supriyanto, Eko. 2018. Ikat Kait Impulsif Sarira. Yogyakarta: Garudhawaca.

Widyastutieningrum, Sri Rochana, and Dwi Wahyudiarto. 2014. Pengantar Koreografi. Edited by Ana

Rosmiati. 1st ed. Surakarta: ISI Press. http://repository.isi-ska.ac.id/3158/. 